\title{
PLANKTONIC CILIATES FROM AN OLIGOTROPHIC SOUTH ANDEAN LAKE, MORENITO LAKE (PATAGONIA, ARGENTINA)
}

\author{
MODENUTTI, B. E. and PÉREZ, G. L. \\ Centro Regional Universitario Bariloche, Universidad Nacional del Comahue, Unidad Postal Universidad, \\ 8400, Bariloche, Argentina \\ Correspondence to: Beatriz E. Modenutti, Centro Regional Universitario Bariloche, Universidad Nacional \\ del Comahue, Unidad Postal Universidad, 8400, Bariloche, Argentina, e-mail: bmode@crub.uncoma.edu.ar \\ Received October 25, 1999 - Accepted December 19, 2000 - Distributed, August 31, 2001
}

(With 9 figures)

\begin{abstract}
In this contribution we have studied the planktonic ciliates from Morenito Lake, an oligotrophic lake situated in the South Andes of Argentina. Six species that are new records for South America or Argentina are described and illustrated. Besides, population dynamics of the ciliate species were studied during a spring-summer period. Strobilidium lacustris and Balanion planctonicum were the most abundant species, showing a maximum in mid summer. Paradileptus elephantinus was present all over the period while Urotricha furcata was observed in late summer samples. Strobilidium lacustris and S. humile were found to be occasional species during the studied period. The recorded ciliate assemblage with oligotrichs and prostomates as dominant indicate the oligotrophic condition of the lake.
\end{abstract}

Key words: planktonic ciliates, taxonomy, population dynamics, South Andes lakes.

\section{RESUMO}

Ciliados planctônicos de um lago oligotrófico dos Andes do Sul, Lago Morenito (Patagônia, Argentina)

Nesta contribuição estudamos os ciliados planctônicos do Lago Morenito, um lago oligotrófico localizado nos Andes do Sul (Argentina). São descritas e ilustradas seis espécies registradas pela primera vez na Argentina e na América do Sul. Durante o período de primavera-verão foram estudadas as dinâmicas populacionais dessas espécies de ciliados. Strobilidium lacustris e Balanion planctonicum foram as espécies mais abundantes, mostrando um máximo na metade do verão. Paradileptus elephantinus esteve presente durante todo o período e Urotricha furcata foi observado em amostras no final do verão. Strobilidium lacustris e $S$. humile foram espécies ocasionais durante o período estudado. O grupo de ciliados registrados com dominância de oligotricos e prostomados indica a condição oligotrófica do lago. Palavras-chave: ciliados planctônicos, taxonomia, dinâmica de população, lagos dos Andes do Sul.

\section{INTRODUCTION}

In the last decades the study of ciliates communities become important since they play a key role in the aquatic microbial food webs in lakes (Beaver \& Crisman, 1989; Müller et al., 1991; Amblard et al., 1993; Macek et al., 1996). Ciliate communities from South Andean lakes have been recently became to be investigated (Modenutti,
1988; Wölfl, 1995; Modenutti, 1997; Modenutti et al., 1997, 1998; Queimaliños et al., 1999).

During these investigations a number of ciliates species were identified and some of them constituted new records for Argentina or South America.

Therefore, in this contribution we studied taxonomically and ecologically six species present in Morenito Lake during a spring-summer period. 


\section{MATERIAL AND METHODS}

This study was performed in Morenito Lake located at $41^{\circ} 3$ ' $\mathrm{S} ; 71^{\circ} 30^{\prime} \mathrm{W}$ and situated at an altitude of $758 \mathrm{~m}$. The lake belongs to the Nahuel Huapi System (Patagonia, Argentina) (Fig. 1, Table 1). The area is included in the Nahuel Huapi National Park. Morenito Lake, was a small bay of Moreno Oeste lake constituting an unique lake until 1960 when a division was artificially settled between them. Therefore, Morenito Lake became delimited as an independent body of water, except when the surface level of the basin is high and a weak connection is re-established. It has a surface area of 83 ha and a maximum depth of $12 \mathrm{~m}$. The thermal regime is continuous cold polymictic, although it eventually freezes in very hard winters. The lake presented very low conductivity values $\left(\approx 60 \mu \mathrm{S} \mathrm{cm}^{-1}\right)$ and dissolved oxygen concentration remained at saturation levels all along the water column. The study was conducted in a central sampling point located at the deepest part of the lake $(\mathrm{z}=12 \mathrm{~m})$.

Between November 1998 and April 1999 the lake was sampled in 9 occasions from 0 to $10 \mathrm{~m}$, each $2 \mathrm{~m}$ interval. The samples were obtained with a Schindler-Patalas trap of $12 \mathrm{~L}$ and this volume was distributed in different sampling bottles for the different purposes.

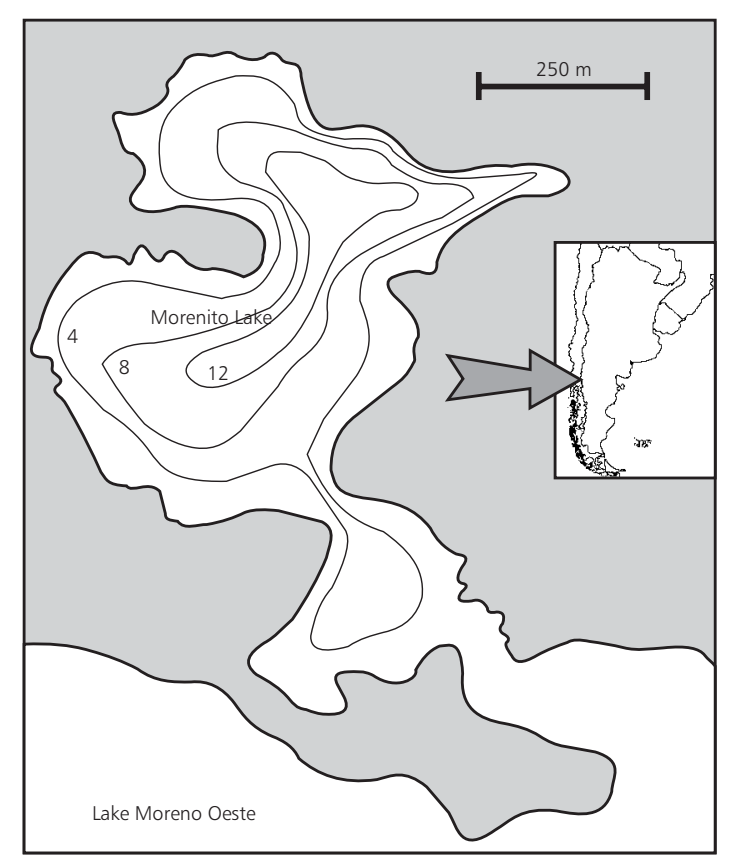

Fig. 1 - Map of the Morenito Lake.
Samples for ciliates were fixed with acid Lugol solution and the different species were quantified with an inverted microscope using 50 $\mathrm{ml}$ Utermöhl chambers. The entire surface of the chamber was examined at $200 \mathrm{x}$ magnification. Ciliate species identification was based mainly on Foissner et al. (1991, 1992, 1994, 1995).

In addition, alive samples were taken and were immediately carried to the laboratory. This samples were examined under a direct microscope Olympus BX50 and images were digitalized with Image Pro Plus Program (Media Cybernectics). Thirty individuals were measured using the same computer program. Measurements are indicated as an average with their calculated standard error.

\section{RESULTS}

\section{Description of the recorded species}

Order Prostomatida

Balanion planctonicum (Foissner, Oleksiv \& Müller) (Fig. 2)

The body is small bursiform with its anterior end transversely truncated, giving it a cup-like appearance. The oral area is circular and surrounded by long finger-like flaps. The body is nearly as wide as the oral area, although some specimens are wider in the middle part of the body.

The somatic ciliature is composed of cilia arranged meridionally. This ciliature is not continuous until the end of the posterior pole, therefore the posterior third of the cell is free of cilia. At the extreme of the pole there is a single caudal cilium which is longer than the rest cilia. The examined specimens showed a cytoplasm stuffed with digestive vacuoles and in the third posterior part of the cell a contractile vacuole was observed.

Dimensions: mean body length $=12.5 \pm 0.4 \mu \mathrm{m}$; mean body width $=10.5 \pm 0.3 \mu \mathrm{m}$.

Comments: this species was listed in plankton samples from lakes Riñihue and Pirehueico in Chile by Wölfl (1995). This record is new for Argentina and species description and illustration are new for South America.

\section{Urotricha furcata Schewiakov (Fig. 3)}

This small prostomatid has a wide oval-shaped cell, with the anterior pole transversely truncated. The widest part is always situated at the middle part of the body. The mouth is located at the anterior po- 
le and was observed to have a funnel-like shape. The edge of the oral zone is surrounded by short flaps.

The somatic ciliature is composed of short cilia arranged meridionally, which are interrupted at the posterior third of the cell. At the posterior pole there are two caudal cilia, considerable longer than the somatic ones.

Dimensions: mean body length $=16.8 \pm 0.6 \mu \mathrm{m}$; mean body width of $13.3 \pm 0.7 \mu \mathrm{m}$.

Comments: this record is new for South America.

\section{Order Oligotrichida}

Strobilidium lacustris Foissner, Skogstad \& Pratt (Figs. 4a and b)

This ciliate has a cone-like body shape. The posterior region is narrower and ends in a short projection like a spine. Although this spine is present in all examined individuals in some ones it is not easily visible. The adoral zone is very conspicuous and is surrounded by membranelles.

In the cytoplasm a C-like shape macronucleus was observed which is situated in the anterior part of the body. A contractile vacuole was also observed located in the posterior part of the body, just above the posterior spine.

Dimensions: mean body length $=58.5 \pm 0.6$ $\mu \mathrm{m}$; mean body width $=45.6 \pm 0.6 \mu \mathrm{m}$.

Comments: this species is recorded for the first time for South America.

\section{Strobilidium humile Penard (Fig. 5)}

This small oligotrich has an oval shape with the anterior pole surrounded by important membranelles constituting a clear adoral zone. This zone form an apical circle that are not extended to ventral side. The wider part of the body is attained at the adoral zone.

The somatic ciliature is reduced and not easily visible. As the whole genus, this species lacks of any kind of lorica.

In the cytoplasm was observed a macronucleus with a $\mathrm{C}$-shape and located in the third anterior part. The contractile vacuole was observed in the third posterior part of the body.

Dimensions: mean body length $=19.2 \pm 1.2 \mu \mathrm{m}$; mean body width $=14.6 \pm 1.3 \mu \mathrm{m}$.

Comments: this species is recorded for the first time for South America.

\section{Strombidium viride Stein (Figs. 6a and b)}

The shape is ovoid, the only visible cilia are those of the adoral zone of membranelles. This adoral zone is extended on ventral side. The somatic ciliature is hardly recognizable. In the middle part of the body a dense girdle can be observed which is conformed by extrusomes. An organic lorica around the base of the cell may be distinguished. This sheath was easy visible in Lugol-fixed specimens, since it is detached from the posterior third of the body (Fig. 6b).

The cytoplasm was always observed plain of food particles giving a yellow green appearance.

This protist has a characteristic swimming pattern. First it makes shaking movements in one place. Then, suddenly it swims rapidly, but with rather short movements, to another place. After that, it restart the movements. The whole action describes a random trajectory.

Dimensions: mean body length $=54,2 \pm 1.2$ $\mu \mathrm{m}$; mean body width $=40.7 \pm 0.4 \mu \mathrm{m}$.

Comments: this is a new record for South America. The species was found to be very abundant and wide spread in Andean lakes from Argentina (Modenutti, personal observation).

\section{Order Gymnostomatida}

\section{Paradileptus elephantinus (Svec) (Fig. 7)}

This large predatory ciliate presents a bursiform shape. The anterior part of the cell has a noncontractile proboscis. The cytostome is localised at the base of the proboscis where it joins the body.

The somatic ciliature is conformed by short cilia along the whole cell surface. The cytoplasm is stuffed with digestive vacuoles, inside of them can be observed rotifers and algae preyed by the ciliate. The macronucleus is moniliform and easily recognizable in living specimens.

Dimensions: mean body length $=230 \mu \mathrm{m} \pm$ 9.5; mean body width $=70 \mu \mathrm{m} \pm 2.8$.

Comments: the species was recorded in Lake El Trébol, in littoral and pelagic samples. In this lake Diéguez \& Balseiro (1998) measured the predation rates of $P$. elephantinus on two species of planktonic rotifers.

\section{DISCUSSION}

\section{Ciliate population dynamics}

During the sampling period Lake Morenito showed no thermal stratification. Temperature was always homogeneously distributed along the water column ranging from $15^{\circ} \mathrm{C}$ (November, March and April) increasing their values up to $21^{\circ} \mathrm{C}$ in the mid 
summer months (January and February). Transparency was fairly constant along the sampling period and the registered $\mathrm{K}_{\mathrm{d}}$ values varied between 0.335 and $0.397 \mathrm{~m}^{-1}$ (Table 1). The dissolved carbon concentration was also very constant along the period $\left(\mathrm{DOC} \approx 2.0 \mathrm{mg} \mathrm{C} \mathrm{L}^{-1}\right.$ ).

In a study of 18 Andean lakes, Modenutti (1997) indicated that ciliate communities differed among them. The large $\left(<5 \mathrm{~km}^{2}\right)$, deep $\left(\mathrm{Z}_{\max }<100 \mathrm{~m}\right)$, ultraoligotrophic lakes of the area were characterized by the presence of the large mixotrophic ciliates: Ophrydium naumanni Pejler and Stentor araucanus Foissner and Wölfl. Morenito Lake correspond to the small and shallow lakes of the area where these large ciliates are not present.

In Morenito Lake the ciliate assemblage was constituted mainly by smaller ciliates $(<50 \mu \mathrm{m})$ with the exception of the predator Paradileptus elephantinus. Ciliates were present during the whole studied period and the maximum densities were attained in mid-summer (January) (Fig. 8).
The assemblage was dominated by the oligotrich Strombidium viride almost all over the period, except in 25 January when the prostomate holotrich Balanion planctonicum developed a high population density (Fig. 8).

The mentioned species are the most important of the ciliate assemblage of Morenito lake, since they constituted the $70 \%$ of total ciliate density (Fig. 8). In addition the large predatory pleurotosmatid Paradileptus elephantinus was found along the sampling period (Fig. 9). The prostomate Urotricha furcata was found mainly in the late summer month (Fig. 9) and the two Strobilidium species (S. lacustris and S. humile) were recorded as occasional species along the studied period (Fig. 9).

Beaver \& Crisman $(1982,1989)$ related the community structure of ciliated protozoa to lake productivity. According to this study, oligotrophic lakes are dominated by Oligotrichida while eutrophic assemblages are codominated by Scuticociliatida, Oligotrichida and Haptorida.

TABLE 1

Limnological parameters of Lake Morenito. Physical and Chemical features corresponded to the studied spring-summer period (November 1998-April 1999). The values are given as average \pm standard error.

\begin{tabular}{|l|c|}
\hline Morphometric parameters & 6.60 \\
\hline Perimeter $(\mathrm{km})$ & 82.94 \\
\hline Surface $(\mathrm{ha})$ & 1.5 \\
\hline Maximum length $(\mathrm{km})$ & 1.28 \\
\hline Maximum width $(\mathrm{km})$ & 4.36 \\
\hline Volume $\left(\mathrm{hm}^{3}\right)$ & 12 \\
\hline Maximum depth $\left(\mathrm{Z}_{\max }\right)(\mathrm{m})$ & 5.26 \\
\hline Mean depth $(\mathrm{m})$ & 2.04 \\
\hline Shore line development & \\
\hline Physical and chemical features & $0.360 \pm 0.007$ \\
\hline Light extinction coefficient $\left(\mathrm{PAR}^{2} \mathrm{~K}_{\mathrm{d}(\mathrm{PAR})}\left(\mathrm{m}^{-1}\right)\right.$ & 12 \\
\hline $\mathrm{Z}_{1 \%}$ PAR $(\mathrm{m})$ & $1.93 \pm 0.04$ \\
\hline Organic carbon concentration $(\mathrm{DOC})\left(\mathrm{mg} \mathrm{C} \mathrm{L}^{-1}\right)$ & $7.52 \pm 0.55$ \\
\hline Total dissolved phosphorus $\left.(\mathrm{TDP})(\mu \mathrm{g} \mathrm{P} \mathrm{L})^{-1}\right)$ & $12.91 \pm 0.96$ \\
\hline Total phosphorus $(\mathrm{TP})\left(\mu \mathrm{g} \mathrm{P} \mathrm{L}^{-1}\right)$ & $1.2 \pm 0.08$ \\
\hline Chlorophyll a concentration $\left(\mu \mathrm{g} \mathrm{L}{ }^{-1}\right)$ & \\
\hline
\end{tabular}



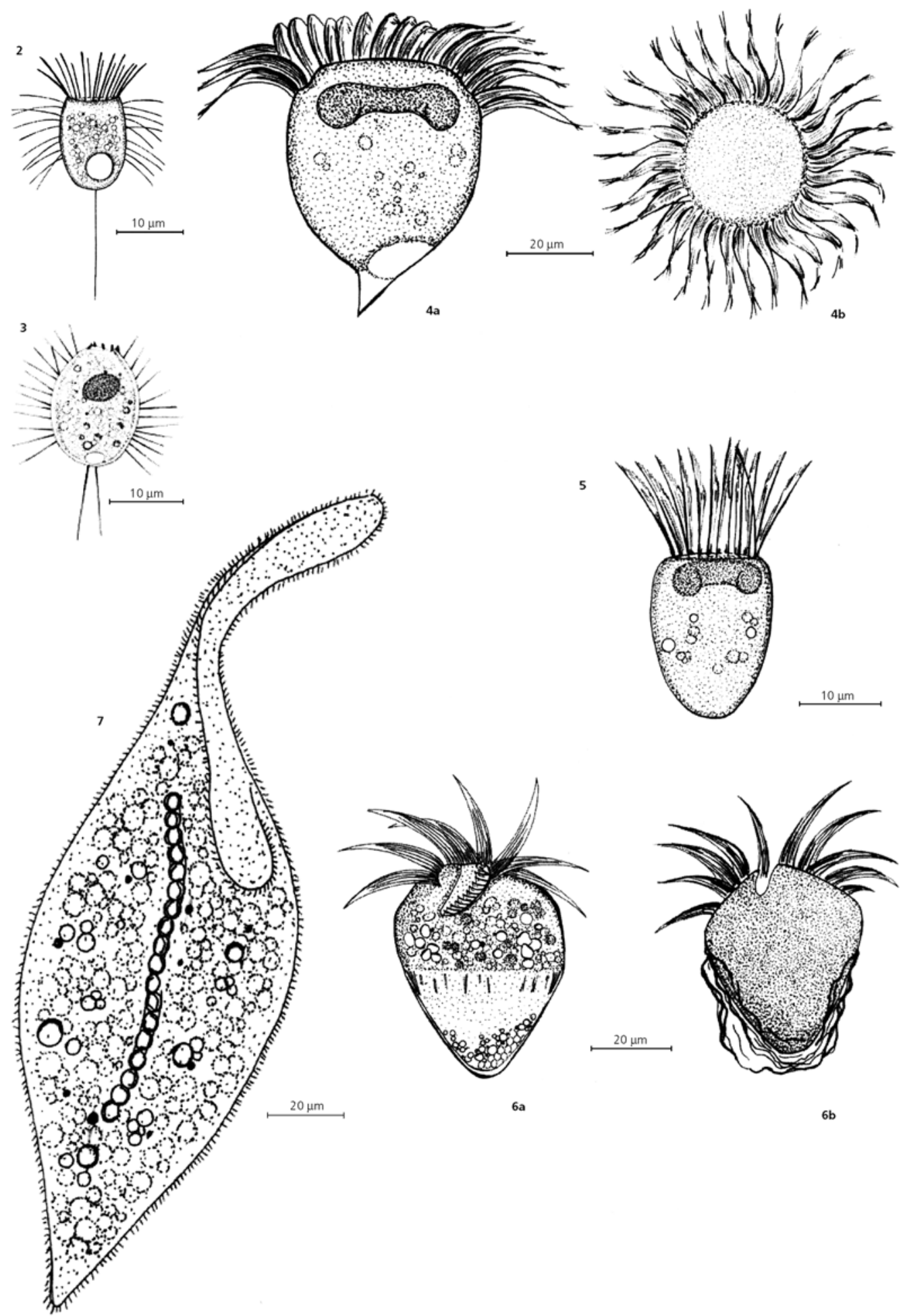

Figs. 2-7 - Planktonic ciliates from Morenito Lake. 2 - Balanion planctonicum (Foissner, Oleksiv \& Müller). 3 Urotricha furcata Schewiakov. $\mathbf{4}$ - Strobilidium lacustris Foissner, Skogstad \& Pratt, $\mathbf{4 a}$ - lateral view, 4b - apical view). 5 - Strobilidium humile Penard. $\mathbf{6}$ - Strombidium viride Stein, $\mathbf{6 a}-$ alive specimen, $\mathbf{6} \mathbf{b}-$ lugol fixed specimen. 7 - Paradileptus elephantinus (Svec). 


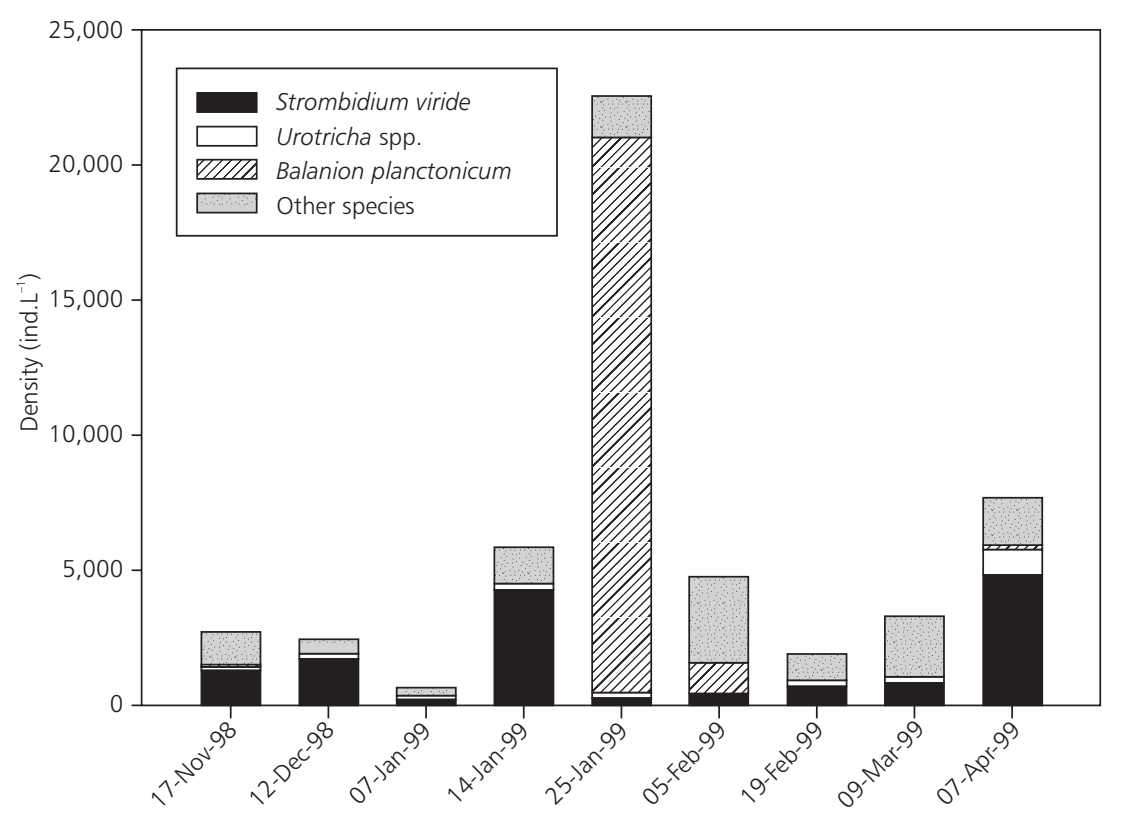

Fig. 8 - Total and dominant ciliate species densities in Morenito Lake during the studied spring-summer period.
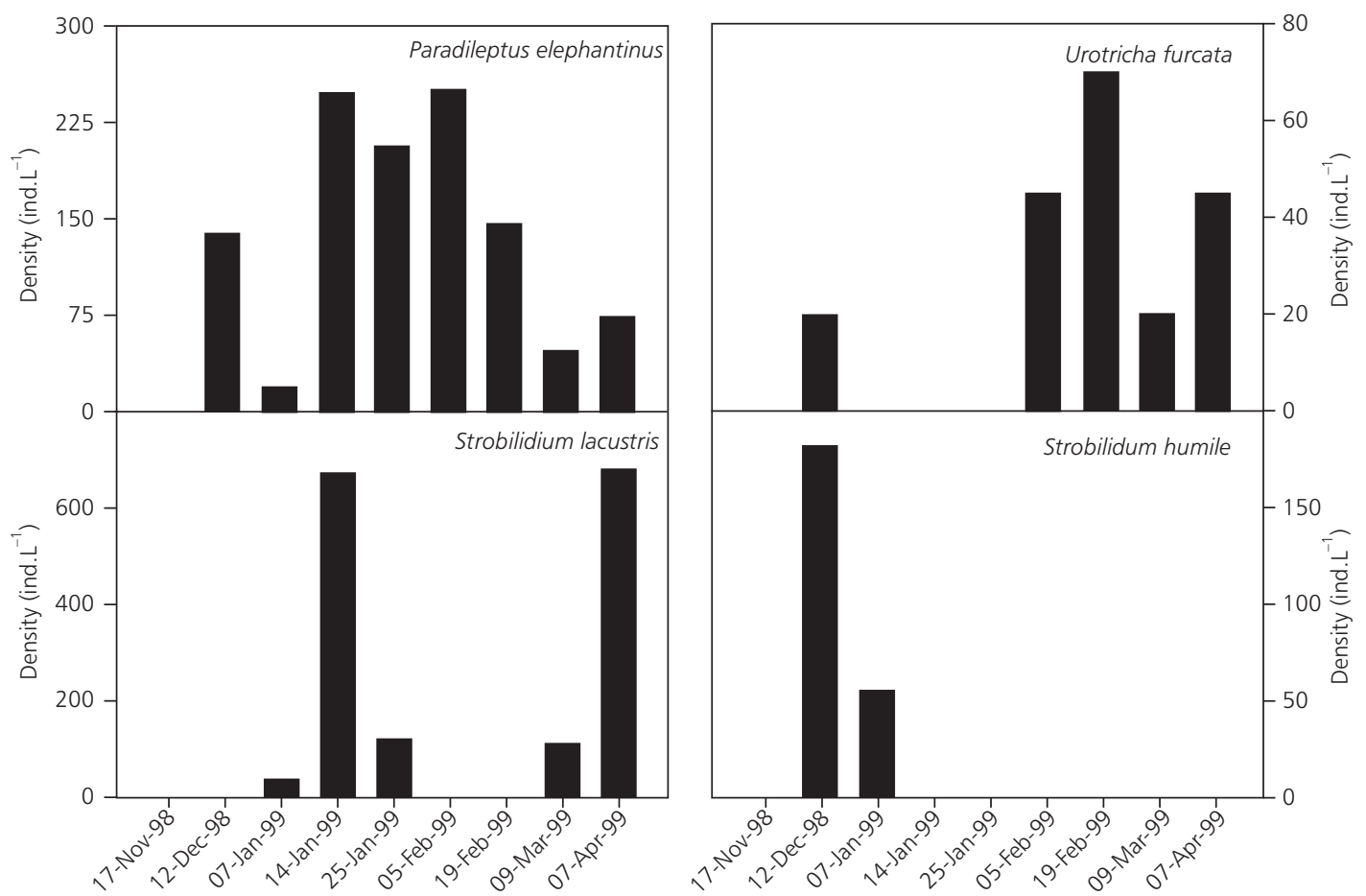

Fig. 9- Paradileptus elephantinus, Urotricha furcata, Strobilidium lacustris and Strobilidium humile densities in Morenito Lake during the studied spring-summer period. 
In Morenito Lake the ciliate community was found to be dominated by oligotrichs and prostomate holotrichs. This constitution resembles that of oligotrophic lakes described by Beaver \& Crisman (1989) and Macek et al. (1996). These ciliates are able to ingest nannoplanktonic algae in addition to bacteria (Beaver \& Crisman, 1982). The taxa registered in Morenito Lake are mainly algivorous raptorial species (Balanion planctonicum, Urotricha furcata) which feed upon nanoflagellates like Rhodomonas (Müller, 1991; Müller et al., 1991).

The presence of Paradileptus elephantinus in Morenito Lake would be also related to food conditions. In this lake, high population densities of the rotifer Polyarthra vulgaris Carlin reaching 900 ind. $\mathrm{L}^{-1}$ have been observed (Modenutti, personal observation). Since $P$. elephantinus was able to ingest that rotifer at high predation rates (Diéguez \& Balseiro, 1998) it is clear that the ciliate has favourable growing conditions in Morenito Lake.

Acknowledgments - This work was supported by ANPCyT Grant 01-06035. We will thank Dr. Balseiro for their help and advices during the study.

\section{REFERENCES}

AMBLARD, C., SIME-NGANDO, T., RACHIQ, S. \& BOURDIER, G., 1993, Importance of ciliated protozoa in relation to the bacterial and phytoplanktonic biomass in an oligo-mesotrophic lake, during the spring diatom bloom. Aquat. Sci., 55: 1-9.

BEAVER, J. R. \& CRISMAN, T. L., 1982, The trophic response of ciliated protozoans in freshwater lakes. Limnol. Oceanogr., 27: 246-253.

BEAVER, J. R. \& CRISMAN, T. L., 1989, The role of ciliated protozoa in pelagic freshwater ecosystems. Microb. Ecol., 17: 111-136.

DIÉGUEZ, M. C. \& BALSEIRO, E. G., 1998, Predation of Paradileptus elephantinus on rotifers. Verh. Int. Ver. Limnol. (in press).

FOISSNER, W., BERGER, H. \& KOHMANN, F., 1992, Taxonomische und ökologische revision der Ciliaten des Saprobiensystems-Band II. Peritrichia, Heterotrichida, Odontostomatida. Informations berichte des Bayer. Landesamtes für Wasserwirtschaf., Heft 5/ 92, 502p.

FOISSNER, W., BERGER, H. \& KOHMANN, F., 1994, Taxonomische und ökologische revision der Ciliaten des Saprobiensystems-Band III. Hymenostomata, Prostomatida, Nassulida. Informationsberichte des Bayer. Landesumtes für Wasserwirtschaf., Heft 1/94, 548 p.
FOISSNER, W., BLATTERER, H., BERGER, H. \& KOHMANN, F., 1991, Taxonomische und ökologische revision der Ciliaten des Saprobiensystems-Band I. Cyrtophorida, Oligotrichida, Hypotrichia, Colpodea. Informationsberichte des Bayer. Landesamtes für Wasserwirtschaft., Heft 1/91, 478p.

FOISSNER, W., BLATTERER, H., BERGER, H. \& KOHMANN, F., 1995, Taxonomische und ökologische Revision der Ciliaten des SaprobiensystemsBand IV. Gymnostomatea, Loxodes, Suctoria. Informationsberichte des Bayer. Landesamtes für Wasserwirtschaft., Heft 1/95, 540p.

MACEK, M., ŠIMEK, K., PERNTHALER, J., VYHNALEK, V. \& PSENNER, R., 1996, Growth rates of dominant planktonic ciliates in two freshwater bodies of different trophic degree. J. Plankton Res., 18: $463-481$.

MODENUTTI, B. E., 1988, Presencia de Ophrydium naumanni Pejler (Ciliophora, Peritricha) en lagos andinos rionegrinos. Neotropica, 36(92): 99-103.

MODENUTTI, B. E., 1997, Distribución de los Ciliados Planctónicos Ophrydium naumanni y Stentor araucanus en Lagos Oligotróficos Andinos. Rev. Soc. Mex. Hist. Nat., 47: 79-83.

MODENUTTI, B. E., BALSEIRO, E. G. \& MOELLER, R., 1998, Vertical distribution and resistance to ultraviolet radiation of a planktonic ciliate Stentor araucanus. Verh. Int. Ver. Limnol., 26: 1636-1640.

MODENUTTI, B. E., BALSEIRO, E. G., QUEIMALIÑOS, C. P. \& DIEGUEZ, M. C., 1997, Protozoos planctónicos de lagos andinos entre los 40 y $41^{\circ}$ de Latitud Sur. II Congreso Argentino de Limnología, 118p.

MÜLlER, H., 1991, Pseudobalanion planctonicum (Ciliophora, Prostomatida): ecological significance of an algivorous nanociliate in a deep meso-eutrophic lake. J. Plankton. Res., 13: 247-262.

MÜLLER, H., SCHÖNE, A., PINTO-COELHO, R. M., SCHEIZER, R. M. \& WEISSE, T., 1991, Seasonal Succession of Ciliates in Lake Constance. Microb. Ecol., 21: $119-138$

QUEIMALIÑOS, C. P., MODENUTTI, B. E. \& BALSEIRO, E. G., 1999, Symbiotic association of the ciliate Ophrydium naumanni with Chlorella causing a deep chlorophyll $a$ maximum in an oligotrophic South Andes lake. J. Plankton Res., 21: 167-178.

WÖLFL, S., 1995, Untersuchungen zur Zooplanktonstruktur einschlieâlich der mikrobiellen Gruppen unter besonderer Berücksichtigung der mixotrophen Cilliaten in zwei südchilenischen Andenfuâseen. Doctoral Thesis, Universität Konstanz, Hartung-Gorre Verlag, 244p. 